\title{
The attitudes and habits of Serbian schoolchildren in consumption of meat
}

\author{
Šarčević Danijela ${ }^{1}$, Đorđević Vesna ${ }^{1}$, Petronijević Radivoj ${ }^{1}$, Matekalo-Sverak Vesna, Karabasil Neđeljko², \\ Popović Ljuba ${ }^{3}$, Janković Vesna
}

A b s tr a c t: The goal of this paper was to explore attitudes and habits of Serbian schoolchildren in consumption of meat. Survey was conducted using self-administrated questionnaire, on a sample of 228 schoolchildren from 7 to 18 years of age, divided into three class groups (I group - from I-IV and II group from V-VIII - Primary school; III group from I-IV-High school). The results showed that all examined schoolchildren had habit to eat meat, except one of them. In regard to the preference, meat and meat products as foodstuff were categorized among schoolchildren as "much liked food" There was statistically significant difference $(p<0.05)$ in explored attitude about consumption of chicken, pork, beef/veal, lamb and venison meat. Schoolchildren of all examined groups primarily consumed chicken meat, followed by pork, beef/veal, and lamb, and at the last place venison. Also, results show that most of schoolchildren usually eat meat prepared at home for one meal per a day, which is in accordance with recommendation provided by Gazette for nutrition of schoolchildren in children's institution of the Republic of Serbia. Responses to the question "How often do you eat meat?" in $21.49 \%$ of total number indicated that eating habits in meat consumption may cause heart problems in schoolchildren population. Survey results showed that schoolchildren primarily eat meat prepared at home, in cooked dishes, as well as grilled or roasted meats. Small percentage (2.68\%) pointed that they consumed meat "three times a day", while $18.86 \%$ do it only once a week or once a month.

Key words: schoolchildren, attitudes, habit, consumption, meat.

\section{Introduction}

Research and knowledge of food and nutrition provide the knowledge of cultural features, content and character related to one nation in some historical period. The choice of food, its classification, the method of obtaining, saving and serving is cultural phenomenon.

Consumer attitudes to meat are influenced by a number of factors, such as price and availability. The major differences, in the volume and type of meat consumed between countries, are thought to be primarily due to differences in culture and eating habits (Flower, 2004; Matekalo-Sverak et al., 2009; Šarčević et al., 2011). Even though some studies have already reported signs of people in industrialized countries eating less meat than before (Fresco, 2009; Troy, 2011), globally the trend is opposite. For instance, Fiala (2008) reports that the consumption of meat worldwide will rise by $72 \%$ between
2000 and 2030, and Steinfeld et al. (2006) projects the global production of meat more than double between 2000 and 2050 due to increasing world population, rising incomes and urbanization.

Serbian cuisine is heterogenic one, although the turbulent historical events influenced the food that people consumed. Strong food is integral part of Serbian tradition and culture. Since livestock production is very developed in Serbia, meat has become the most preferred type of nutrient. Historically, meat has been a scarce and highly appreciated foodstuff, a source of energy and protein, and palatable food carrying the images of strength, power of masculinity. For many Serbian families a meal without meat is a rare exception. But, today consumers pay much more attention to health aspects of meat. Nutritional value of the meat in human nutrition is well known, and the importance that meat has in human nutrition is understandable. There are 14 key reasons why meat is considered nutritionally

Acknowledgments: This paper was supported by the Ministry of Education, Science and Technological Development of the Republic of Serbia, Project III 46009.

${ }^{1}$ Institute of Meat Hygiene and Technology, Kaćanskog 13, 11000 Belgrade, Republic of Serbia;

2University of Belgrade, Faculty of Veterinary Medicine, Bulevar oslobođenja 18, 11000 Belgrade, Republic of Serbia;

${ }^{3}$ Ministry of Agriculture, Forestry and Water Management, Nemanjina 22-26, 11000 Belgrade, Republic of Serbia.

Corresponding author: Đorđević Vesna, vesna@inmesbgd.com 
valuable. Namely, meat is exceptional source of proteins, vitamin B12, vitamin B6, thiamine, niacin, selenium, zinc and phosphorus. It is very good source of riboflavin and potassium, also of iron and pantothenic acid (Baltic et al., 2011; Verbeke, 2010). In Serbian cuisine chicken meat is most commonly consumed, beside the pork, while beef/veal, lamb and venison are less common, primarily because of price. It is worth to mention that in Serbian eating habit, venison meat used to be very represented in the meal, but today it is very rare. Although, hunting tourism is developed in Serbia, venison meat is exported to neighbouring countries, because it is too expensive, and less available to consumers.

Today, there is growing interests in children's eating habits and potential health consequences. Increased availability of indigenous and "westernized" energy fast foods, aggressive advertising practices, relatively low cost and improved purchasing power, have led children and adolescents to increase the consumption of the saturated fat snacks. Such rapid changes in dietary practices, accompanied by increasingly sedentary lifestyle, leads to child obesity. (Rosenkrantz and Dzewaltowski, 2008). Childrens' food preferences are strongly influenced by their parents' dietary habits (Nicklas et al., 2001). Thus, in order to develop childrens' preferences toward meat, parents have to encourage them to consume meat. In a sample of middle school students, parental modelling predicted adolescent meat consumption (Young et al., 2004). Home social influence may impact eating behaviours consciously or unconsciously via attitudes, subjective norms, mimicry, awareness and involvement (Kremers et al., 2006). Parental acceptance of the meat nutritional recommendations in their own dietary practices may serve to underline attempts to ensure healthful dietary practices of the children (Brewis and Gartin, 2006).

The purpose of this paper was to provide information about the meat consumption of Serbian schoolchildren aged 7-18, with focus on chicken, pork, poultry, beef/veal, lamb and venison meat.

\section{Methodology}

The sample frame for this research consisted of schoolchildren from one elementary and one high school in one Belgrade municipality in the Republic of Serbia.

Convenience sampling was used and questionnaire was distributed to all schoolchildren who agreed to participate after they were informed about the goals of this research. A total of 228 respondents participated in this study. For the purpose of further analyses, the sample was divided by age in three subgroups - respondents from elementary school, I group (I-IV class, and age from 7-11 years), and II group (V-VIII class, and age from 11-14 years), and respondents from high school, III group (I-IV class, age $15-18$ years).

The questionnaire used in this study consisted of the following groups of questions - knowledge about meat, attitudes and habits. The questionnaire was distributed among the respondents, self-administrated and collected after three days.

The descriptive statistics and analysis of variance were used for data processing, in Excel Microsoft Office program.

\section{Results and discussion}

In this study, the hypothesis was that schoolchildren in elementary school usually consume meal prepared at home, created by their parents. Parents' education and nutritional knowledge might have long term effects on many health outcomes. Vereecken et al (2004) have established that better maternal nutritional knowledge was associated with better diets for children, although their influence increased with child age. The schoolchildren in high school are considered to be under many various influences, such as advertising, trends, popular nutrition advices, and, therefore, they rather consume fast food.

Results of our survey, presented in Table 1, show that $100 \%$ of schoolchildren of the I and III

Table 1. The percentage of responses to the question "Do you eat meat"

Tabela 1. Procentualni prikaz odgovora na pitanje „Da li jedete meso?”

\begin{tabular}{|c|c|c|c|}
\hline & $\begin{array}{c}\text { Elementary school/ } \\
\text { Osnovna škola } \\
\text { I-IV class (\%) }\end{array}$ & $\begin{array}{c}\text { Elementary school/ } \\
\text { Osnovna škola } \\
\text { V-VIII class (\%) }\end{array}$ & $\begin{array}{c}\text { High school/ } \\
\text { Srednja škola } \\
\text { I-IV class (\%) }\end{array}$ \\
\hline $\mathrm{Yes} / \mathrm{Da}$ & 100.00 & 98.70 & 100.00 \\
\hline $\mathrm{No} / \mathrm{Ne}$ & 0.00 & 1.30 & 0.00 \\
\hline
\end{tabular}




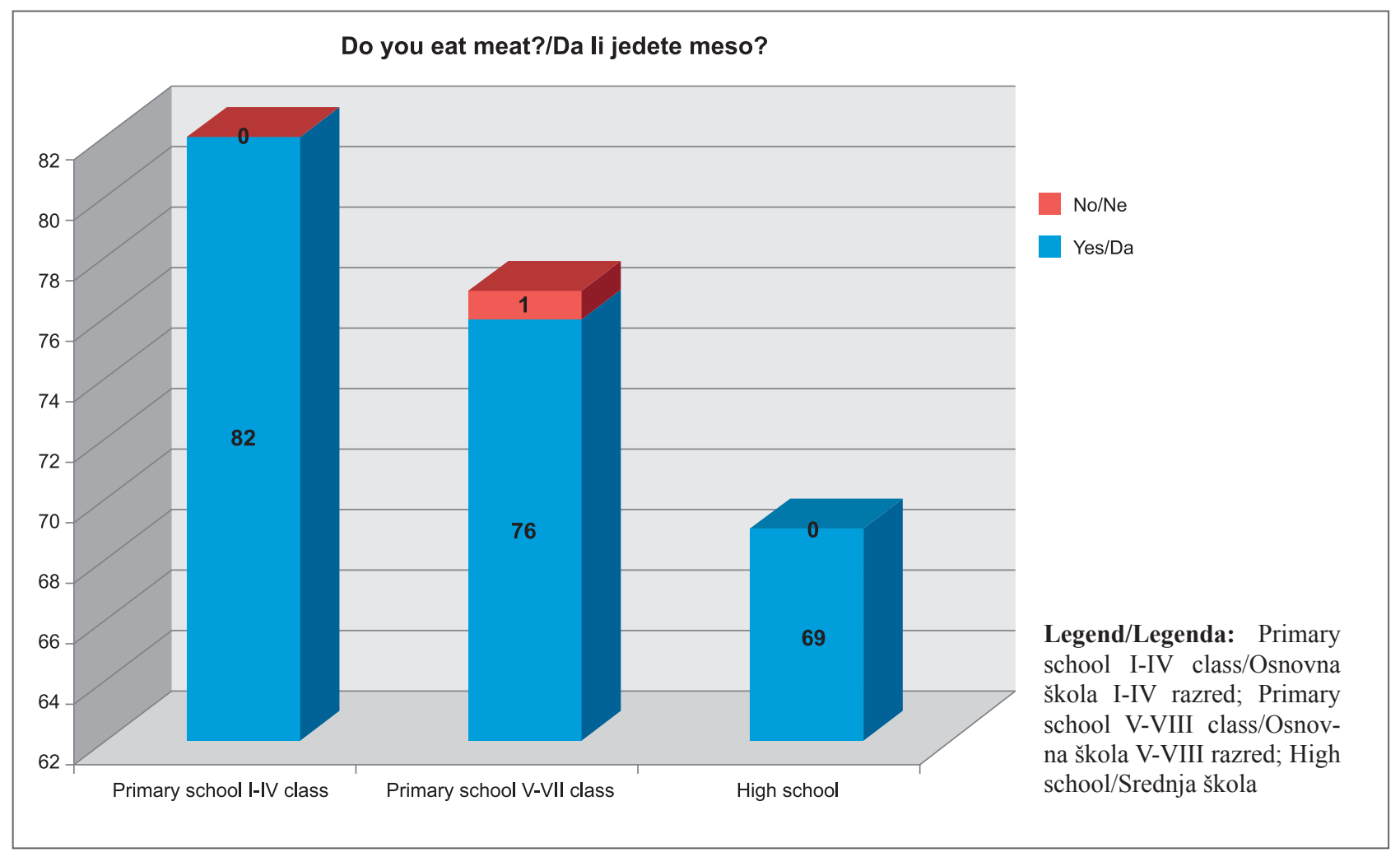

Figure 1. Do you eat meat?

Slika 1. Da li jedete meso?

group (I-IV class of the elementary school and I-IV class of the high school), and $98.70 \%$ of schoolchildren from the II group (class V-VIII of the elementary school) consumed meat . Similar to our investigation, in year 2007 The Australian National
Children's Nutrition and Physical Activity survey was conducted in aim to provide data on nutrition and meat consumption of Australian children (Bowen et al., 2012). The data indicates that $90 \%$ of the reported children (age groups 4-8 years; 9-13 years

Table 2. The percentage of responses to the question "Do you like to eat meat?"

Tabela 2. Procentualni prikaz odgovora na pitanje „Da li volite da jedete meso?“

\begin{tabular}{|l|c|c|c|}
\hline & $\begin{array}{c}\text { Elementary school/ } \\
\text { Osnovna škola } \\
\text { I-IV class (\%) }\end{array}$ & $\begin{array}{c}\text { Elementary school/ } \\
\text { Osnovna škola } \\
\text { V-VIII class (\%) }\end{array}$ & $\begin{array}{c}\text { High school/ } \\
\text { Srednja škola } \\
\text { I-IV class (\%) }\end{array}$ \\
\hline $\begin{array}{l}\text { I like it very much/ } \\
\text { Mnogo mi se sviđa }\end{array}$ & 60.98 & 52.00 & 55.07 \\
\hline $\begin{array}{l}\text { I like it/ } \\
\text { Sviđa mi se }\end{array}$ & 29.27 & 38.67 & 39.13 \\
\hline $\begin{array}{l}\text { It's good/ } \\
\text { Dobro je }\end{array}$ & 9.76 & 9.33 & 5.80 \\
\hline $\begin{array}{l}\text { I don't like it/ } \\
\text { Ne sviđa mi se }\end{array}$ & 0.00 & 0.00 & 0.00 \\
\hline $\begin{array}{l}\text { I don't like it at all/ } \\
\text { Uopšte mi se ne sviđa }\end{array}$ & 0.00 & 0.00 & 0.00 \\
\hline
\end{tabular}




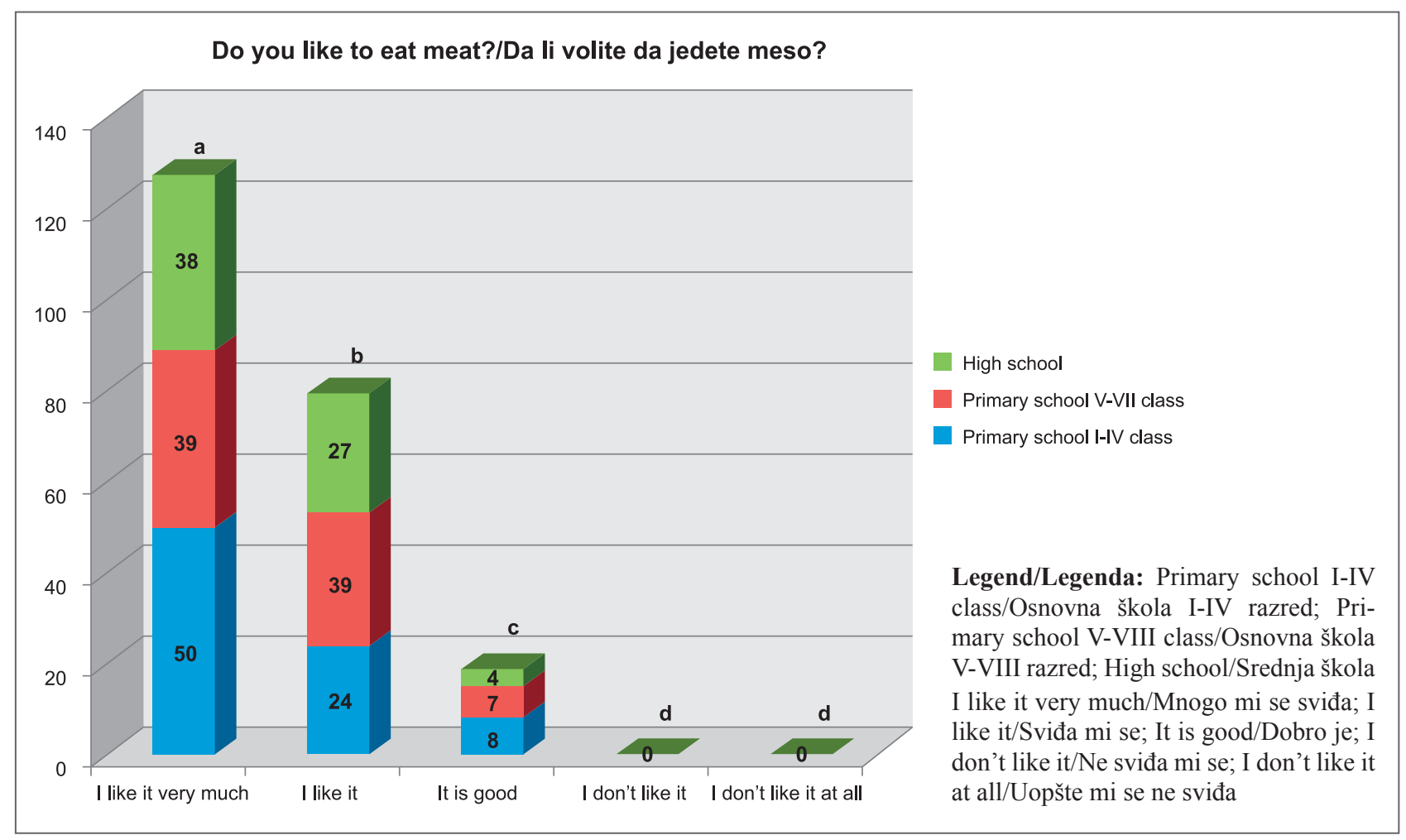

Figure 2. Level of preference in consumption of meat by schoolchildren

Slika 2. Stepen dopadljivosti u konzumiranju mesa kod školske dece

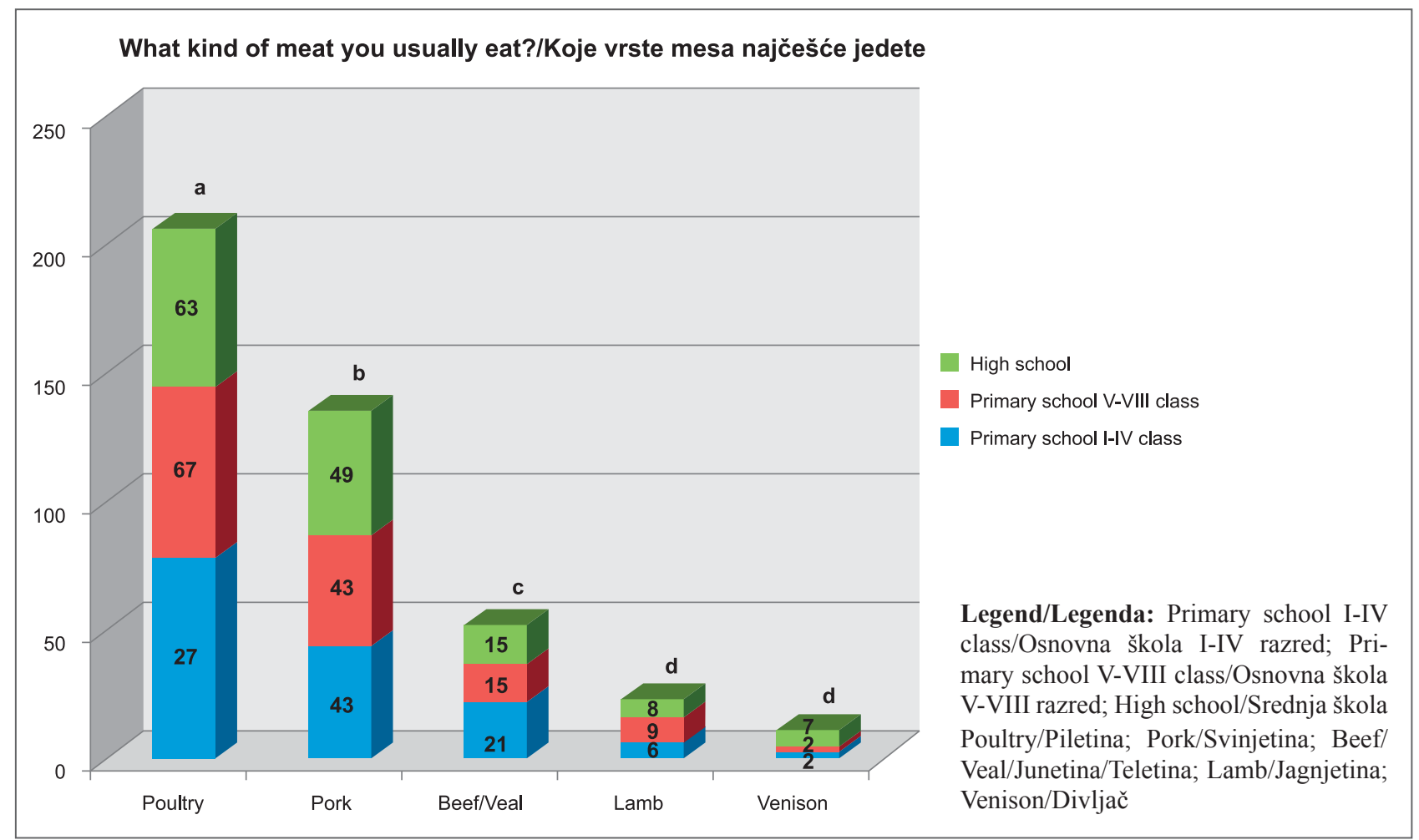

Figure 3. Type of meat commonly consumed by schoolchildren

Slika 3. Prikaz vrste mesa koje najčešće jedu školska deca 


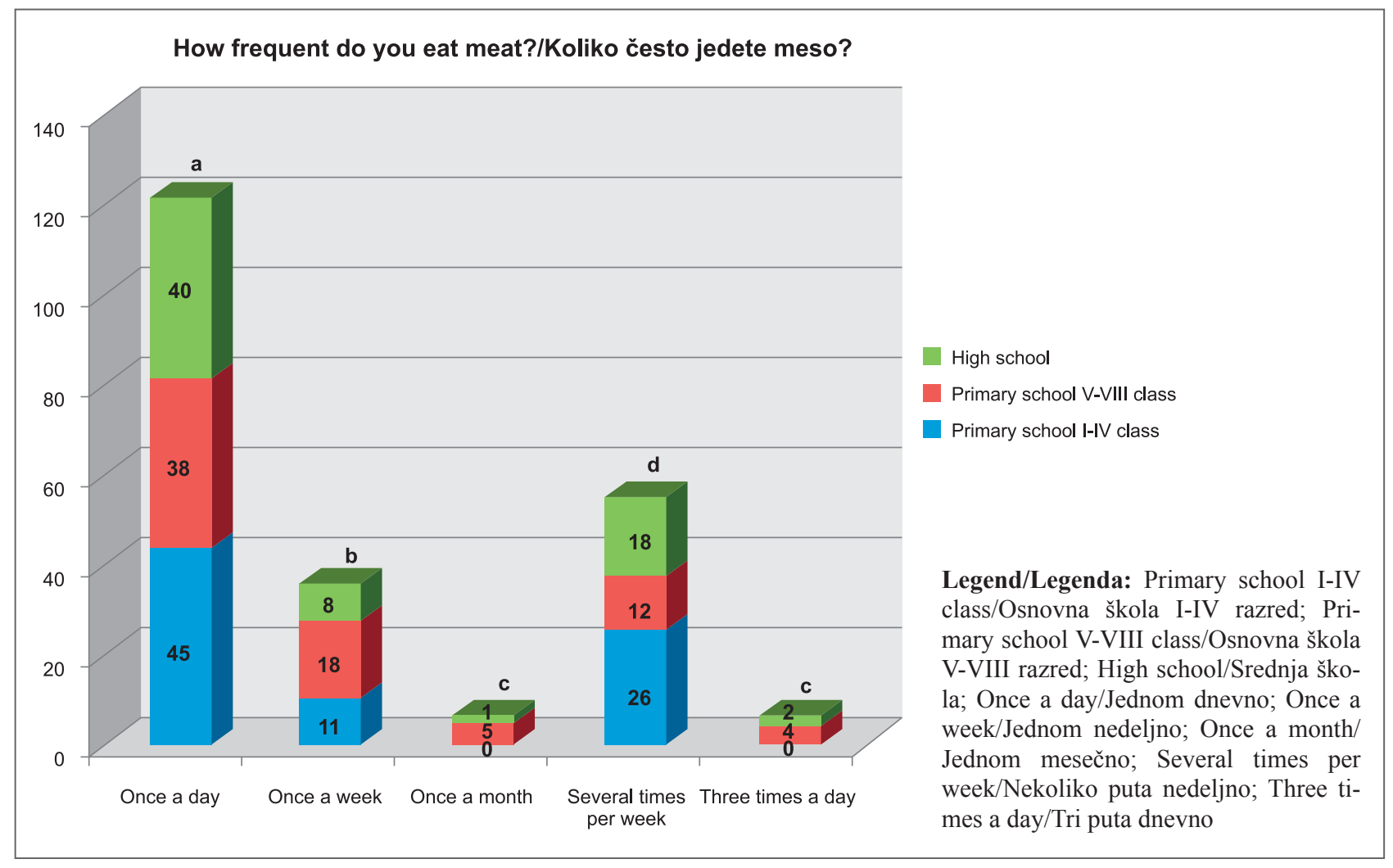

Figure 4. The frequency of the meat consumption by schoolchildren

Slika 4. Prikaz učestalosti konzumiranja mesa kod školske dece

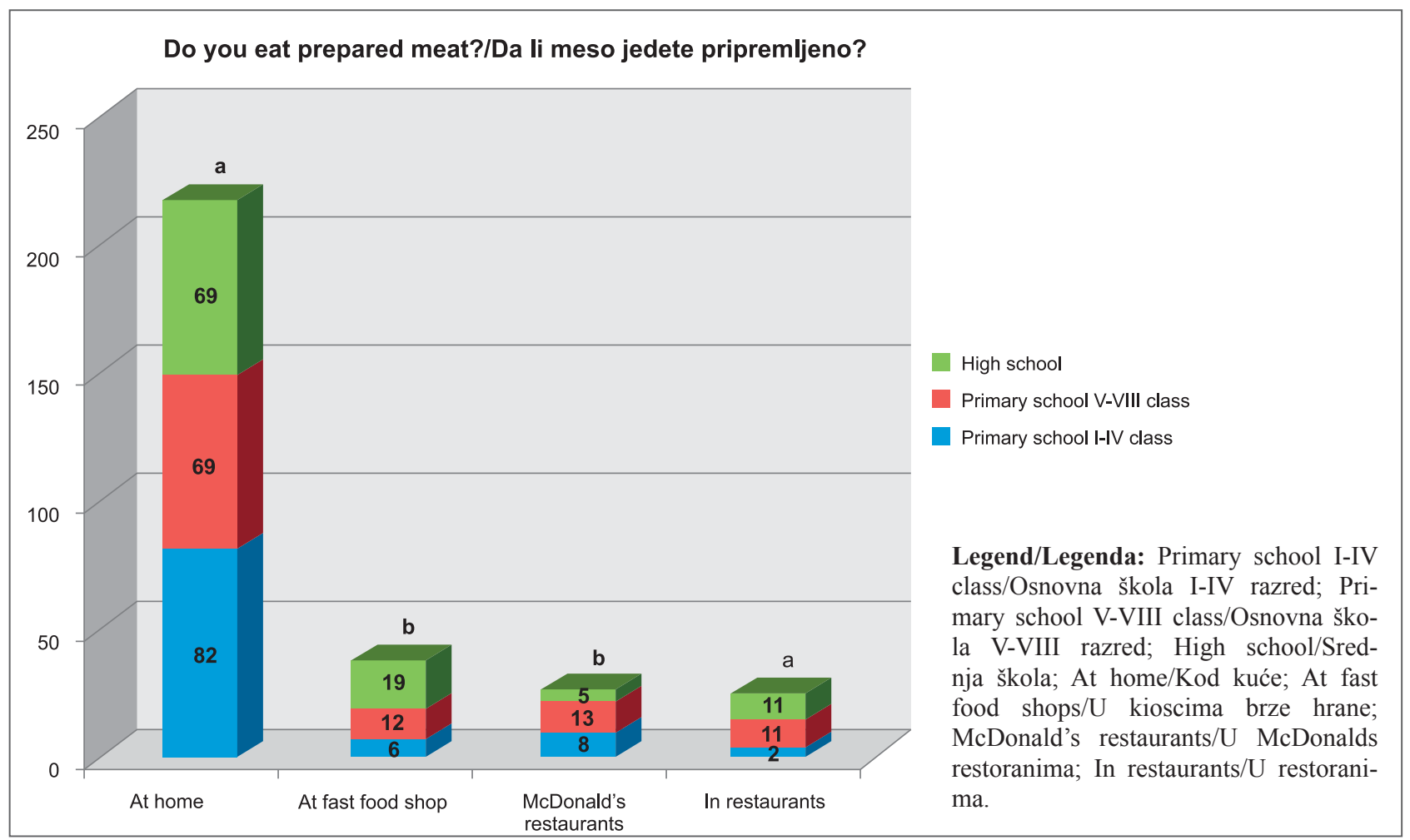

Figura 5. Locations where the meat is most common consumed by schoolchildren

Slika 5. Prikaz mesta gde školska deca najčešće jedu meso 
and 14-16 years) consume poultry, pork, beef/veal and lamb, which is very close to the results we obtained. Also, this is in accordance with previous statements regarding the position of meat in Serbian attitudes and eating habits, as very important nutrient in everyday use.

Table 2 and Figure 2 show results, i.e. answers to the question "Do you like to eat meat", as follows: $60.98 \%$ of the schoolchildren of the I group answered with "I like it very much" and results from II (52.00\%) and III (55.07\%) group were almost similar. In category of schoolchildren from high school (III group), 39.13\% answered „I like it“, while $29.27 \%$ of schoolchildren from I group, and $38.67 \%$ from II group had the same answer. Small percentage of schoolchildren choose the answer „It's good“, 9.76\% in I group, 9.33\% in II group and $5.80 \%$ in the III group. Answers „I don't like it“" and „I don't like it at all“ were not chosen at all. Survey results related to type of meat that schoolchildren consumed in diet, showed a statistically significant difference between the first of three meat species (chicken $48.48 \%$, pork $31.62 \%$, beef/veal $11.94 \%$ ), at the $95 \%$ of confidence interval ( $\mathrm{p}<$ $0.05)$. There was no statistically significant difference in amount of lamb (5.39\%) and venison (2.58 $\%)$ that children use in diet (Figure 3). Bowen et al.
(2012), in the previously mentioned Australian survey, have noticed that approximately one third of all meat consumed was beef/veal/lamb (34-37\% across age groups), and almost a third was poultry (27-37\% across age groups). The relative proportion of poultry meat increased with age, while in our study it decreased as schoolchildren got older.

The analysis of variance to the question „How often do you eat meat? " showed statistically significant difference in the frequency of meat consumption. Most of examined schoolchildren, of all three groups, consumed meat once a day. This result is in accordance with recommendation provided by Gazzete for nutrition of schoolchildren in children institutions (Official Gazzete RS 600/02-44/94), determining the protein amount for full day meal, including children age, body mass specific to age categories, which is $10 \%$ of the total energy value for meat. Insufficient intake of meat causes stunted growth and development, reduced body mass, resistance to diseases, reduction of red blood cells which results with anaemia problems. Adults should consume $1 \mathrm{~g}$ per $\mathrm{kg}$ of body weight, while children have to consume two to three times more (60-90 $\mathrm{g}$ of meat daily). German Association for Nutrition recommends $0.9 \mathrm{~g}$, and in USA this amount is $0.8 \mathrm{~g} / \mathrm{kg}$ body weight daily (Radetić and Matekalo

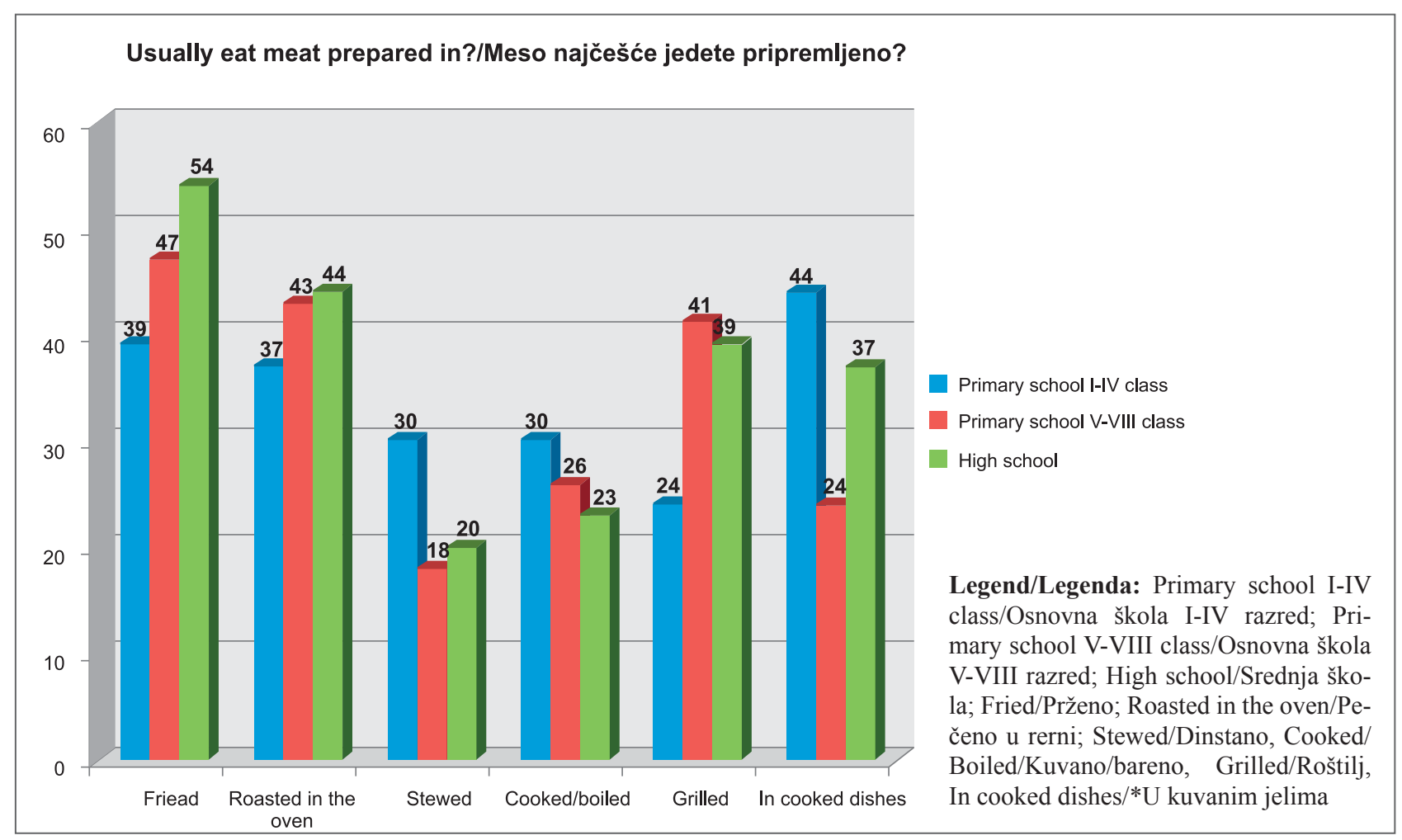

Figura 6. The most common preparation manner of meat consumed by schoolchildren Slika 6. Prikaz načina pripreme na koji školska deca najčešće jedu meso 
Sverak, 2013). Only one meal per day should include meat, preferably poultry and fish, but other types of meat has not to be avoided. Daily intake of pork, or repeated daily intake of pork, might cause heart problems and might lead to heart attack and stroke, as well as to other diseases (Radetić and Matekalo Sverak, 2013). Obtained results of our survey ( $21.49 \%$ of the total number of respondents) indicate eating habits in meat consumption that may cause heart problems in schoolchildren population. Small percentage $(2.68 \%)$ indicated that they consumed meat ,three times a day“, while $18.86 \%$ do it only once a week or once a month. Over half of the responses $(55.10 \%)$ of the above three categories of respondents, have been provided by schoolchildren from V to VIII grade of the elementary school.

Results related to the place where meat was prepared, confirmed by ANOVA analysis, showed that schoolchildren primarily consumed meat prepared at home. Consumption of meat, prepared in restaurants and fast food kiosks were equally represented, but to lesser extent than home prepared meat (Figure 5). Bowen et al. (2012) have noted that most meat and poultry consumption occurs in the home environment. This is very important result from both surveys, because, according to our opinion, it gives very dispersive space for some nutritive health recommendations for schoolchildren aged from $7-18$ years.

Figure 6 illustrates the results of different ways of preparing meat, which respondents indicate they are using in their diet. There are some differences, but the analysis of variance showed no significant differences in the way of preparing the meat.

For the schoolchildren of the I group, the primary consumption of meat was in cooked dishes, as well as, grilled and roasted meat. According to survey results in this group, grilled meat was the least

\section{References}

Baltić Ž. M., Marković R., Đorđević V., 2011. Nutrition and meat quality. Tehnologija mesa, 52, 1, 154-159.

Bowen J., Baird D., Syrette J., Noakes M., Baghurst K., 2012. Consumption of beef/veal/lamb in Australian children: Intake, nutrient contribution and comparison with other meat, poultry and fish categories. Nutrition \& Dietetics, 69, 2, 1-16.

Brewis A., Gartin M., 2006. Biocultural construction of obesogenic ecologies childhood: parent feeding versus childeating strategies. American Journal of Human Biology, 18, 203-213.

Fiala N., 2008. Meeting the demand: an estimation of potential future greenhouse gas emissions from meat production. Ecological economics, 67, 412-419. used in diet. On the other hand, older schoolchildren, especially from II group, generally consumed meat which was fried, baked or grilled This group of respondents least used in their diet meat simmered/ stewed or cooked, or meat in cooked dishes. The situation is similar among the schoolchildren of III group, who consumed most commonly fried meat in their diet, while stewed meat was least used, with exception of the amount of meat they consumed in cooked dishes.

\section{Conclusion}

In accordance with the obtained results in our study the following can be concluded:

- Although meat is nutritionally significant ingredient in Serbian cuisine, it was accepted in the diet of schoolchildren which was aging 7-18;

- Survey results show that the focus in the diet is shifted from pork to chicken meat, which is in line with the recommendations of the above mentioned medical associations and regulation.

- Most of the examined schoolchildren aging 7-18 years consumed meat once a day, which is in line with recommendation of Gazette for nutrition of schoolchildren in children' institutions. According to this, Serbian schoolchildren population consumes meat in healthy way.

The results, also, indicate that schoolchildren of III group prefer to consume roasted meat. They do it rather at home, than in fast food kiosks. This gives the possibility to extend more education about healthy eating habits and implementation in daily meal schedule, bought to parents and schoolchildren.

Flower T., 2004. European meat consumption. Meat demand trends, meat and livestock commission: Milton Keynes, United Kingdom.

Fresco 1. O., 2009. Challenges for food system adaptation today and tomorrow. Environmental Science \& Policy, 12, 378-385.

Gazette on nutrition of schoolchildren in children institutions 1994. Official Gazette RS 600/02-44/94.

Kremers S. P., de Brujin G. J., Visscher T. L., van Mitchelen W., de Vires N. K., Brug J., 2006. Environmental influences on energy balanced - related behaviors: a dual process view. International Journal of Behavior Nutrition and Physical Activity. 
Matekalo-Sverak V., Turubatovic L., Petronijevic R., 2009. Producers in improvement of the control of the quality of meat products - consumer protection strategy. Tehnologija mesa, 50, 1-2, 2009.

Nicklas T. A., Baranovski T., Baranovski J. C., Cullen K., Rittenberry L., Olivera N., 2001. Childcare provider influences on preschool children's' fruit, juice and vegetable consumption. Nutrition Review, 59, 224-235.

Radetić P., Matekalo-Sverak V., 2013. Monograph „Meat“, II supplemented issue, the electronic version, 58.

Rosenkranz R., Dzewaltowski D., 2008. Model of the house environment pertaining to childhood obesity. Nutrition Review, 66, 123-140.

Steifield H., Gerber P., Wassernaar T., Castel V., Rosales M., de Haan C., 2006. Livestock's long shadow. Environmental issue and options. Rome: Food and Agriculture Organization of the United Nations. www. ftp.fao.org
Šarčević D., Lilić S., Đorđević V., Milićević D., Vranić D., Lakićević B., Milijašević M., 2011.The role of consumers' perception and attitude in purchasing of meat and meat products. Tehnologija mesa, 52, 2, 283-290.

Troy D., 2011. Modern approaches to enhancing beef quality. Tehnologija mesa, 52, 1, 15-22.

Verbeke W., Pèrez-Cueto F. J. A., de Barcellos M. D., Krystallis A., Grunet K. G., 2010. European citizen and consumer attitudes and preferences regarding beef and pork. Meat Science, 84, 284-292.

Vereecken C. A., Keukelier E., Maers L., 2004. Influence of mother's educational level of food parenting practices and food habits of young children. Appetite, 2004, 43, 93-103.

Young E. M., Fors S. W., Hayes D. M., 2004.Associations between perceived parent behaviors and middle school children fruit and vegetable consumption. Journal of Nutritional Education Behavior 36, 2-8.

\title{
Stavovi i navike školske dece u Srbiji u konzumiranju mesa
}

\author{
Šarčević Danijela, Đorđević Vesna, Petronijević Radivoj, Matekalo-Sverak Vesna, Karabasil Neđeljko, \\ Popović Ljuba, Janković Vesna
}

R e z i m e: Cilj ovog rada bio je da se ispitaju satvovi i navike školske dece u Srbiji u konzumiranju mesa i proizvoda od mesa. Istraživanje je sprovedeno korišćenjem upitnika, na uzorku od 228 školske dece, uzrasta 7 do 18 godina, podeljene u tri grupe (od I-IV i V-VIII razreda osnovne i I - IV razreda srednje škole). Rezultati su pokazali da, osim jednog deteta, sva ispitana deca koriste meso u ishrani. Po pitanju dopadljivosti, meso i proizvodi od mesa su namirnice koje se među decom kategorišu kao „,mnogo mi se sviđa“. Statistički značajna razlika $(p<0,05)$ pokazala se u stavovima đaka prilikom konzumiranja pilećeg, svinjskog i junećeg/ telećeg, jagnjećeg i mesa divljači. Takođe, rezultati su pokazali da školska deca, obično, jedu meso kod kuće, bar za jedan obrok, što je u skladu sa preporukama Pravilnika o normativima društvene ishrane dece u ustanovama za decu Republike Srbije. Odgovori na pitanje „, Koliko često jedete meso? ", u 21,49\% školske dece, ukazuju na činjenicu da bi način na koji deca konzumiraju meso mogao da dovede do srčanih oboljenja. Rezultati istraživanja pokazuju da školska deca primarno jedu meso koje je pripremljeno kod kuće, kako kuvano, tako i pečeno i prženo. Mali procenat ispitane školske dece (2,68\%) se izjasnio da jede meso „, tri puta dnevno “, dok $18,86 \%$ dece konzumira meso jednom nedeljno, ili jednom mesečno.

Ključne reči: školska deca, stavovi, navike, konzumacija, meso.

Paper received: 4.12.2013.

Paper accepted: 10.12.2013. 